\title{
Trafficking of $\mathrm{GABA}_{\mathrm{A}}$ Receptors, Loss of Inhibition, and a Mechanism for Pharmacoresistance in Status Epilepticus
}

\author{
David E. Naylor, Hantao Liu, and Claude G. Wasterlain \\ Department of Neurology, Veterans Administration Greater Los Angeles Healthcare System and University of California, Los Angeles, Los Angeles, \\ California 90073
}

\begin{abstract}
During status epilepticus (SE), GABAergic mechanisms fail and seizures become self-sustaining and pharmacoresistant. During lithiumpilocarpine-induced $\mathrm{SE}$, our studies of postsynaptic $\mathrm{GABA}_{\mathrm{A}}$ receptors in dentate gyrus granule cells show a reduction in the amplitude of miniature IPSCs (mIPSCs). Anatomical studies show a reduction in the colocalization of the $\beta 2 / \beta 3$ and $\gamma 2$ subunits of $\mathrm{GABA}_{\mathrm{A}}$ receptors with the presynaptic marker synaptophysin and an increase in the proportion of those subunits in the interior of dentate granule cells and other hippocampal neurons with SE. Unlike synaptic mIPSCs, the amplitude of extrasynaptic $\mathrm{GABA}_{\mathrm{A}}$ tonic currents is augmented during SE. Mathematical modeling suggests that the change of mIPSCs with SE reflects a decrease in the number of functional postsynaptic $\mathrm{GABA}_{\mathrm{A}}$ receptors. It also suggests that increases in extracellular [GABA] during SE can account for the tonic current changes and can affect postsynaptic receptor kinetics with a loss of paired-pulse inhibition. GABA exposure mimics the effects of SE on mIPSC and tonic $\mathrm{GABA}_{\mathrm{A}}$ current amplitudes in granule cells, consistent with the model predictions. These results provide a potential mechanism for the inhibitory loss that characterizes initiation of SE and for the pharmacoresistance to benzodiazepines, as a reduction of available functional $\mathrm{GABA}_{\mathrm{A}}$ postsynaptic receptors. Novel therapies for SE might be directed toward prevention or reversal of these losses.
\end{abstract}

Key words: $\mathrm{GABA}_{\mathrm{A}}$ receptor trafficking; status epilepticus; epilepsy; hippocampus; math model; synaptic inhibition

\section{Introduction}

Status epilepticus (SE) affects $>100,000$ people each year in the United States and carries a 27\% mortality with high morbidity in survivors, and little progress has been made in understanding the pathophysiology or improving treatment in the last 40 years (DeLorenzo et al., 1996). We do not understand why, in SE, seizures tend to become self-sustaining or why benzodiazepines are effective early in the course of SE but may sustain a 20 -fold loss of potency by $30 \mathrm{~min}$ and fail to arrest SE by $45 \mathrm{~min}$ (Kapur and Macdonald, 1997; Mazarati et al., 1998b; Treiman et al., 1998). Indeed, the rapid evolution of seizure activity and timedependent loss of pharmacological response is one of the reasons for a lack of therapeutic progress (Treiman, 1995; Treiman et al., 1998). In this study, we found a functional loss of postsynaptic $\mathrm{GABA}_{\mathrm{A}}$ receptors and a marked internalization of $\mathrm{GABA}_{\mathrm{A}}$ receptor subunits by $1 \mathrm{~h}$ of $\mathrm{SE}$, associated with a pronounced loss of GABAergic synaptic inhibition. These results may explain, in part, the transition from single seizures to pharmacoresistant self-sustaining SE.

\section{Received Dec. 5, 2004; revised July 7, 2005; accepted July 12, 2005}

This work was supported by a Veterans Administration Career Development Award (D.N.) and a Merit Review Award (C.W.) and by National Institute of Neurological Disorders and Stroke Grant N13515 (C.W.). We are indebted to Istvan Mody for numerous suggestions and advice and benefited from interactions and feedback from members of his group, including Brandon Stell and Kimmo Jensen. We also thank Jerome Engel Jr and Kerry Thompson for review of this manuscript.

Correspondence should be addressed to Dr. David E. Naylor, Veterans Administration Greater Los Angeles Healthcare System and University of California, Los Angeles, Building 500 Neurology (127), 11301 Wilshire Boulevard, Los Angeles, CA 90073. E-mail:dnaylor@ucla.edu.

DOl:10.1523/JNEUROSCI.4944-04.2005

Copyright $\odot 2005$ Society for Neuroscience $\quad$ 0270-6474/05/257724-10\$15.00/0

\section{Materials and Methods}

Electrophysiological recordings: whole-cell patch clamp

Four- to seven-week-old male Wistar rats (Simonsen Laboratories, Gilroy, $\mathrm{CA}$ ) received lithium ( $3 \mathrm{mEq} / \mathrm{kg}$, i.p.; the previous night $)$ and methylscopolamine (1 mg/kg, s.c.) $30 \mathrm{~min}$ before either pilocarpine $(40 \mathrm{mg} /$ kg, i.p.) (Sigma, St. Louis, MO) or normal saline. All animal studies were approved by the Institutional Animal Care and Use Committee. After $\sim 1$ $\mathrm{h}$ from the onset of stage 5 seizures (Racine, 1972), animals were anesthetized with halothane and then decapitated, and the brains were placed in ice-cold artificial CSF (ACSF) containing the following (in mM): 126 $\mathrm{NaCl}, 2.5 \mathrm{KCl}, 2 \mathrm{CaCl}_{2}, 2 \mathrm{MgCl}_{2}, 1.25 \mathrm{NaH}_{2} \mathrm{PO}_{4}, 26 \mathrm{NaHCO}_{3}, 10$ D-glucose, 1 pyruvate, 0.3 ascorbic acid, and 3 kynurenic acid (Sigma), $\mathrm{pH}$ 7.3. Coronal sections $(350 \mu \mathrm{m})$ (Leica VT1000S; Leica, Bannockburn, IL) were held in a chamber at room temperature bubbled with $95 \%$ $\mathrm{O}_{2}$ and $5 \% \mathrm{CO}_{2}$ until transfer to a chamber perfused at $1.5 \mathrm{ml} / \mathrm{min}$ with $33-35^{\circ} \mathrm{C} \mathrm{ACSF}$, in which recordings from somata of visualized neurons were made using an Axoclamp-2B amplifier (Molecular Devices, Foster City, CA). While blocking indirect circuitry effects with $1 \mu \mathrm{M}$ tetrodotoxin (Calbiochem, La Jolla, CA), some slices from lithium control animals were incubated in $40 \mathrm{mg} / \mathrm{L}$ pilocarpine for $\sim 1 \mathrm{~h}$ to control for a direct pharmacological effect of pilocarpine. Electrode solutions for miniature IPSC (mIPSC) recordings contained the following (in $\mathrm{mM}$ ): $140 \mathrm{CsCl}, 4 \mathrm{NaCl}, 2 \mathrm{MgCl}_{2}, 10$ HEPES, 0.05 EGTA, and $2 \mathrm{Mg}$-ATP (Sigma) (holding potential, $-70 \mathrm{mV}$ ). For polysynaptic-evoked IPSC recordings, the electrode solution was composed of the following (in mM): $130 \mathrm{Cs}$-gluconate, $10 \mathrm{CsCl}, 2 \mathrm{MgCl}_{2}, 10$ HEPES, 0.05 EGTA, 5 tetraethylammonium-Cl, and $2 \mathrm{Mg}$-ATP. The holding potential for evoked events was $0 \mathrm{mV}$ with bipolar electrode stimulation (MicroProbe, Gaithersburg, MD) via the perforant path (pulses, 40-100 V; $0.1-0.15 \mathrm{~ms}$ ). Electrode solutions were titrated to $\mathrm{pH} 7.25$ with an osmolarity of 280-300 mOsm. Borosilicate electrodes were pulled (Sutter Instruments, Novato, CA) for a resistance of $4-6 \mathrm{M} \Omega$, and recordings with series resistance changes exceeding $50 \%$ were excluded. 


\section{Solutions and drugs}

ACSF for mIPSC recordings contained $1 \mu \mathrm{M}$ tetrodotoxin and $3 \mathrm{~mm}$ kynurenic acid. ACSF for tonic $\mathrm{GABA}_{\mathrm{A}}$ currents contained $10 \mu \mathrm{M}$ 1-[2[[(diphenylmethylene)imino] oxy]ethyl]-1,2,5,6-tetrahydro-3-pyridinecarboxylic acid hydrochloride (NO711) with $1 \mu \mathrm{M} \mathrm{GABA}$, and 2-(3carboxypropyl)-3-amino-6-(4-methoxyphenyl)-pyridazinium bromide (SR95531) was applied directly to the recording chamber by pipette for a final concentration of $100 \mu \mathrm{M}$ (Sigma). For select mIPSC recordings, diazepam (10 mg/L; Abbott Laboratories, Chicago, IL) was added to the perfusate. It was difficult to detect differences in tonic currents between SE and control cells without the addition of inhibitors of GABA uptake. For select experiments, higher concentrations of GABA $(\leq 100 \mu \mathrm{M})$ were added to the perfusate. No drugs were added to the ACSF for evoked recordings.

\section{Data analysis}

After $3 \mathrm{kHz}$ low-pass filtering with $20 \mathrm{kHz}$ digitizing (Digidata 1200; Molecular Devices), event detection and analysis [e.g., peak amplitude, rise-time, and area-under-the-curve (AUC)] software was generously provided by I. Mody (University of California, Los Angeles, Los Angeles, CA). Analysis of tonic current mean and variance used 40-50 epochs of $100 \mathrm{~ms}$ (devoid of IPSCs) sampled every $200 \mathrm{~ms}$. A Student's $t$ test was used to assess statistical significance.

\section{Computer modeling}

Math modeling of measurable physiology was to characterize $\mathrm{GABA}_{\mathrm{A}}$ receptor kinetic properties, postsynaptic numbers, amount and duration of exposure to cleft GABA, and receptor conductance. The modeling used personal programs written for MatLab (MathWorks, Natick, MA). mIPSCs with absolute peak amplitudes exceeding 100 pA were excluded. For channels with open probability, $P_{\text {open }}$, the binomial distribution for the population of channels at a synapse generating mIPSCs has the following mean current $(I)$ :

$$
I=N \times P_{\text {open }} \times i
$$

and variance $\left(\sigma^{2}\right)$

$$
\sigma^{2}=N \times P_{\text {open }} \times\left(1-P_{\text {open }}\right) \times i^{2}
$$

(Zar, 1999), where $N$ is the number of postsynaptic receptors per synapse, and $i$ is the open channel current. These equations were adapted to allow variability in the number of postsynaptic receptors for the individual mIPSCs of a cell. In view of the bimodal amplitude distribution of mIPSCs (see Fig. 3C), we assumed that the number of receptors per single synapse for control and SE cells (Table 1) corresponded with the distribution peak for the subgroup of smaller amplitude mIPSCs. $P_{\text {open }}$ varies depending on $[\mathrm{GABA}]$. Model parameters for a seven-state $\mathrm{GABA}_{\mathrm{A}}$ receptor (Table 1) and for the peak and exponential decay of cleft [GABA] determine $P_{\text {open }}$ (probability of the two open states) at the synapse. These parameters that determine $P_{\text {open }}$ and those for $N$ and $i$ were optimized using Equations 1 and 2 to fit the measured mean $(I)$ and SD $(\sigma)$ of mIPSCs from individual cells.

The assumption of a uniform current ( $i$ ) for synaptic receptors is not unreasonable, because single conductance states primarily characterize the synaptic, $\gamma 2$ subunit-containing receptors (Brickley et al., 1999; Lorez et al., 2000). The choice of the seven-state receptor model (Table 1) was based on single-channel and outside-out patch recordings, suggesting at least two open states (Jones and Westbrook, 1995; Haas and Macdonald, 1999) and slow (desens $\left.{ }_{1}\right)$ and fast $\left(\right.$ desens $_{2}$ ) desensitized states (Overstreet et al., 2000). The proportion of receptors in fast and slow desensitized states depends on the concentration of GABA (Overstreet et al., 2000), suggesting that a rate constant dependent on [GABA] (such as the path between bound ${ }_{1}$ and bound ${ }_{2}$ ) intervenes between the two desensitized states.

For tonic currents, $P_{\text {open }}$ is determined by extracellular [GABA], and the number of receptors $(N)$ is now per cell, not per synapse. Substituting Equation 1 into Equation 2 determines the following parabolic equation:

$$
\sigma^{2}=i \times I-I^{2} / N
$$

allowing $N$ and $i$ determination from optimized fits of tonic current SD versus mean plots (see Fig. $5 B$ ). The relationship of $P_{\text {open }}$ to extracellular [GABA] was calibrated by optimizing parameters for seven-state $G_{A B A}$ receptors to fit means and SDs from experiments in control slices using known $[\mathrm{GABA}]$ in the perfusate $(3,5$, and $10 \mu \mathrm{M})$.

Evoked IPSC models interpret stimulated responses as sums of all activated individual IPSCs, allowing temporal dispersion for the arrival of the postsynaptic currents to the granule cell (with subsequent filtering by the granule cell). Adjustable parameters include the number of synapses activated and time constants $(\tau)$ for bandpass filters of the following form: $\left(1+i \omega \tau_{1}\right) /\left[\left(1+i \omega \tau_{2}\right) \times\left(1+i \omega \tau_{3}\right)\right]$. The filters were scaled to preserve the charge transfer of individual synapses. Previous fits of control mIPSCs provide values for the $\mathrm{GABA}_{\mathrm{A}}$ receptor kinetics, GABA cleft release, receptor conductance, and number of postsynaptic receptors per synapse (Table 1, column 2). These values were fixed constants during this evoked IPSC optimization. After determining the evoked IPSC values for the number of synapses and filter constants, simulated paired pulses (interstimulus interval of $40 \mathrm{~ms}$ ) were delivered to a fixedparameter model. The simulated paired-pulse responses were performed applying synaptic control (Table 1, column 3) or SE (Table 1, column 2) parameter values.

\section{Numerical methods}

mIPSCs. $P_{\text {open }}$ is determined by the GABA receptor kinetic parameters (Table 1) and varies over the course and thereby determines the shape of an mIPSC (based on the transient effect of quantal release on the two binding kinetic parameters that are dependent on cleft [GABA]). The number of postsynaptic receptors at a particular synapse and current $(i)$ through the individual receptors are constant for single mIPSCs and will not affect shape but will, at any given $P_{\text {open }}$, determine the amplitude and relationship between mean $(I)$ and SD $(\sigma)$ of mIPSCs (as defined by Eq. 3 ). Simultaneous fitting the mean and SD of mIPSC traces adds necessary constraint for the determination of receptor numbers and current $(i)$. Assuming a random (Markov) process for fluctuations between the openings and closings of a channel, model mIPSCs were generated by matrix multiplication of $A$ (where $A$ is $7 \times 7$, the particular value of the matrix indexed by $j$ and $k, A_{j k}$, is the probability that a receptor in state $k$ will transition to state $j$ during a specified time increment of iteration) by $x_{\mathrm{n}}(7 \times 1$; containing the probability of each state at the current time), thereby generating the time-updated probability vector, $x_{\mathrm{n}}+1$, to be substituted for $x_{\mathrm{n}}$ in subsequent iterations $\left(A \times x_{\mathrm{n}}=x_{\mathrm{n}+1}\right) . P_{\text {open }}$ is the sum of the probabilities from each of the two open states of $x_{n}$. The time increment per iteration was $0.01 \mathrm{~ms}$, with successive iterations through a total of $20 \mathrm{~ms}$ representing a single trial. For each trial, the values for $P_{\text {open }}$ at each time point of the trial and the values for $i$ and $N$ (constant for all time points of the trial) were used to generate model traces for the mean and SD of mIPSCs (applying modifications of Eqs. 1 and 2) for comparison with the experimental traces. The errors between model and data were minimized across successive trials using a simplex algorithm (Lagarias et al., 1998).

The general strategy for modeling mIPSCs was to make initial estimates of $i$ and $N$ values by optimizing the variables of Equation 3 to fit variance versus mean plots for mIPSCs. Next, estimates for synaptic $\mathrm{GABA}_{\mathrm{A}}$ receptor kinetic parameters and cleft [GABA] were obtained by methods independent of $i$ and $N$, which involved fitting only the shape/ time course of the mean and SD of mIPSCs. Allowing free-scaled normalization of the model amplitude to match the actual mIPSC amplitude permits removal of $i$ and $N$ as parameters, because $i$ and $N$ are fixed across the time course of an mIPSC and, hence, will not affect its shape. Finally, a complete model fit the mean and SD of mIPSCs (including amplitudes) with free parameters for $\mathrm{GABA}_{\mathrm{A}}$ receptor kinetics, cleft [GABA], and $i$ and $N$ values together using the initial estimates obtained by the earlier two steps as starting points.

Tonic currents. No dynamic change in $P_{\text {open }}$ occurs because extracellular $[\mathrm{GABA}]$ is stable (unlike synaptic vesicular GABA release). For given [GABA],$x_{\text {equil }}(7 \times 1$; representing the equilibrium probability of each state, including the two open states that determine $\left.P_{\text {open }}\right)$ is determined by solution of the equilibrium equation $A_{\text {equil }} \times x_{\text {equil }}=0$ (where $A_{\text {equil }}$ is $7 \times 7$; the particular value indexed along row $j$ and column $k$ of 
the matrix is the rate of transition from state $k$ to state $j$ ). The equilibrium solution $\left(x_{\text {equil }}\right)$ characterizes each of the probabilities of the seven receptor states that occur for a balance to exist between the rates entering and exiting each state (with zero net change in the probability of any state).

\section{Immunocytochemistry}

Serial formaldehyde-fixed $40 \mu \mathrm{m}$ coronal sections were incubated overnight in mouse anti- $\beta 2 / \beta 3$ (or $\gamma 2$ ) $\mathrm{GABA}_{\mathrm{A}}$ subunit antiserum $(5 \mu \mathrm{g} / \mathrm{ml}$; Chemicon, Temecula, $\mathrm{CA}$ ) and rabbit anti-synaptophysin antiserum (5 $\mu \mathrm{g} / \mathrm{ml}$; Zymed, San Francisco, CA). The sections were incubated for $1 \mathrm{~h}$ in FITC-labeled goat anti-rabbit IgG (1:200; Jackson ImmunoResearch, West Grove, PA) and 3-cyano coumarin (Cy3)-labeled donkey antimouse IgG (1:500; Jackson ImmunoResearch) diluted in PBS containing $1 \%$ goat serum, horse serum, and $0.3 \%$ Triton X-100. For quantification of immunofluorescent receptors, a Z-series of optical images through control and SE hippocampi was acquired at $100 \times$ with a confocal cellscanning microscope (Scanalytics, Fairfax, VA) and processed using Image Pro Lab Spectrum software (Media Cybernetics, Silver Spring, MD). Immunoreactive receptor puncta were defined as discrete points along the neuron and dendrite with fluorescence intensity at least twice the background staining. Colocalization was determined by examination of the overlaid synaptophysin and receptor-stained images, in which the percentage overlap referred to the ratio of colocalized puncta over the total number of subunit puncta. We counted all $\beta 2 / \beta 3$ subunitimmunoreactive cell bodies (average of 21 per section in the dentate gyrus, 18 in CA1) and 20 proximal dendrites $(25 \mu \mathrm{m}$ in length per section) in four sections per animal. In control hippocampi, $\beta 2 / \beta 3$ subunit immunoreactivity distributed predominantly to the neuronal surface, and few $\beta 2 / \beta 3$ subunit-immunoreactive neurons had more than five endosome-like structures per cell body. Cell bodies with $>15 \beta 2 / \beta 3$ subunit-immunoreactive endosome-like structures were considered to display subunit internalization. Alternatively, $\mathrm{GABA}_{\mathrm{A}}$ receptor-positive neurons for anti- $\beta 2 / \beta 3$ (or $\gamma 2$ ) were manually outlined, and MetaMorph software (Universal Imaging, West Chester, PA) used fluorescent intensity ratios to measure the number of internalized relative to total $\mathrm{GABA}_{\mathrm{A}}$ subunit-immunoreactive puncta for the neuron. Accurate $\gamma 2$ subunit-LI puncta counts for dentate granule cells was difficult with this methodology based on soma outlines, because $\gamma 2$ subunit-LI density on the soma is lower than dendrites in these cells. A Student's $t$ test was used to determine statistical significance. Data are expressed as the number of overlaps per soma and dendrite.

\section{Results}

\section{SE causes relocation of $\mathrm{GABA}_{\mathrm{A}}$ receptor subunits from} synapses to the cell interior

In granule and pyramidal cells from control hippocampi, immunoreactivity against the $\beta 2 / \beta 3$ subunits of $\mathrm{GABA}_{\mathrm{A}}$ receptors (red pseudocolor) localizes to discrete puncta, which outline the cell membrane, and frequently colocalizes with the (green) presynaptic marker synaptophysin-like immunoreactivity (LI), giving these overlaps a yellow color (Fig. 1). After $1 \mathrm{~h}$ of SE, much of this $\beta 2 / \beta 3$ subunit-LI relocates to the cell interior, which is surrounded by the synaptophysin-LI (Fig. 1, right, bottom). In hippocampal granule cells, the proportion of $\beta 2 / \beta 3$ subunit-LI, which overlaps synaptophysin-LI, is reduced from $43 \pm 10 \%$ in controls to $13 \pm 4 \%$ in SE $(p<0.001$; all data as mean $\pm \mathrm{SD} ; n=$ 3 animals per group). The absolute number of overlaps between synaptophysin-LI and $\beta 2 / \beta 3$ subunit-LI on granule cells decreases from $9 \pm 1$ on the somatic surface of controls to $3 \pm 1$ with SE and from $10 \pm 2$ for the $25 \mu \mathrm{m}$ proximal dendrites of controls to $3 \pm 2$ with SE ( $p<0.001 ; n=3$ animals per group). In the hilus, the number of overlaps is decreased by $69 \pm 19 \%$ in somata ( $72 \pm 20 \%$ for dendrites) during SE, and CA1 pyramidal neurons show similar reductions (CA1 soma, $65 \pm 15 \%$; dendrite, $70 \pm 18 \%)$. Using fluorescence intensity, the ratio of internal over total puncta for $\beta 2 / \beta 3$ subunit-LI increases from $0.09 \pm$ 0.03 in granule cells of controls $(0.15 \pm 0.08$ for hilar cells $)$ to

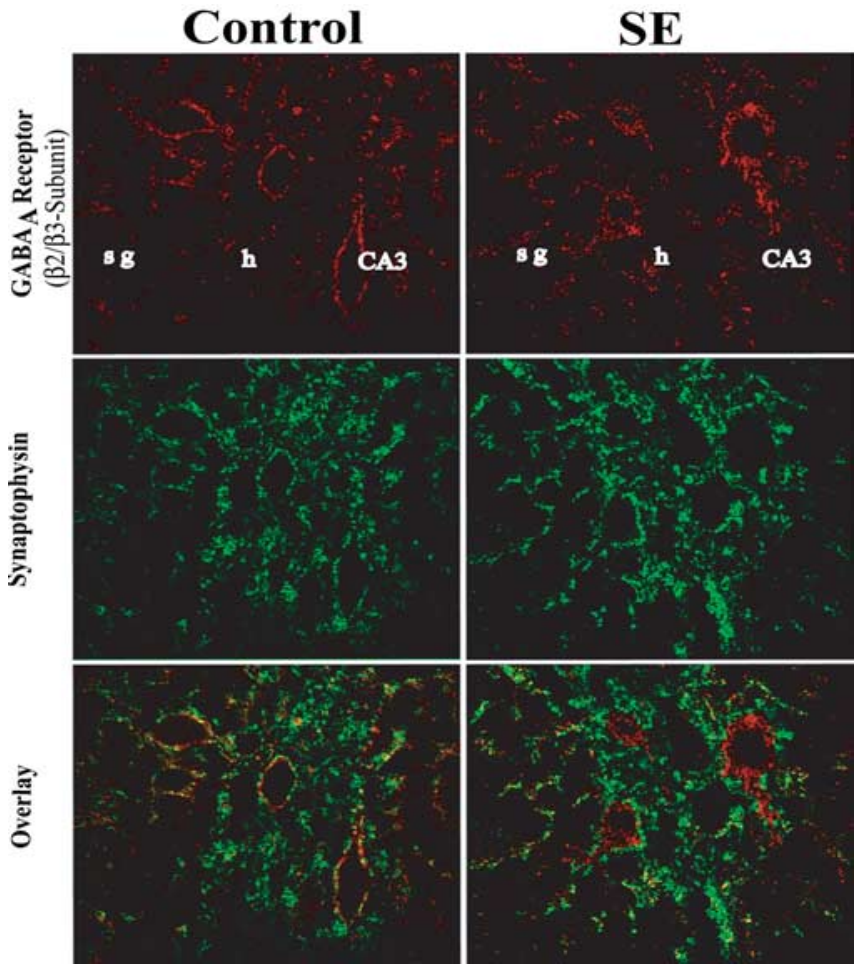

Figure 1. Subcellular distribution of $G_{A B A_{A}} \beta 2 / \beta 3$ subunits with SE. Hippocampal sections of control (left) and SE (right) stained with an antibody against $\mathrm{GABA}_{\mathrm{A}} \beta 2 / \beta 3$ subunits (red, top) and an antibody against the presynaptic marker synaptophysin (green, middle). Overlaps between presynaptic synaptophysin and postsynaptic $\mathrm{GABA}_{\mathrm{A}}$ subunit appear yellow (bottom). Note that fewer $\mathrm{GABA}_{\mathrm{A}}$ subunit puncta colocalize with synaptophysin with greater internalization of the red receptor subunits relative to the green synaptophysin outline during SE (right, bottom), suggesting trafficking of $\mathrm{GABA}_{\mathrm{A}}$ subunits. sg, Stratum granulosum; $\mathrm{h}$, hilus.

$0.82 \pm 0.09$ during SE $(0.85 \pm 0.05$ for hilar cells; $p<0.001)$. By a separate method, the number of cells displaying $\beta 2 / \beta 3$ subunit-LI in the cell interior (defined as having $>15$ endosomelike puncta per cell interior) increases from $9.7 \pm 0.6 \%$ of control granule cells to $71 \pm 5 \%$ after SE, and CA1 pyramids show a similar change $(7.3 \pm 2.3 \%$ in controls; $70 \pm 3 \%$ in SE; $p<$ $0.001)$. These changes are not seen when seizures are prevented by injecting atropine with the pilocarpine (data not shown). Internal relocation of $\beta 2 / \beta 3$ subunit-LI is also observed in SE induced by intrahippocampal injection of neurokinin B or by perforant path stimulation (data not shown). At the same time, immunoreactivity for the NR1 subunit of NMDA receptors moves in the opposite direction from cytoplasmic sites to the cell surface with an increase in the number of overlaps with synaptophysin (D.E. Naylor, H. Liu, and C.G. Wasterlain, unpublished observations), suggesting that the direction of trafficking during $\mathrm{SE}$ is type specific for receptors and not a general phenomenon. Both the $\mathrm{GABA}_{\mathrm{A}}$ and NMDA changes would be expected to increase excitability in the midst of seizures and thus appear maladaptive.

Because we and others have observed a rapid decrease in benzodiazepine potency during SE in several animal models (Kapur and Macdonald, 1997; Mazarati et al., 1998b), we studied the $\gamma 2$ subunit, which contributes to benzodiazepine binding (Gunther et al., 1995; Saxena and Macdonald, 1996) and associates with the AP2 adaptin-clathrin complex involved with endocytosis (Connolly et al., 1999; Kittler et al., 2000). After 1 h of lithiumpilocarpine SE, overlaps between the $\gamma 2$ subunit and synaptophysin are reduced from $8.3 \pm 0.9$ (soma) and $10 \pm 0.6$ (proximal 


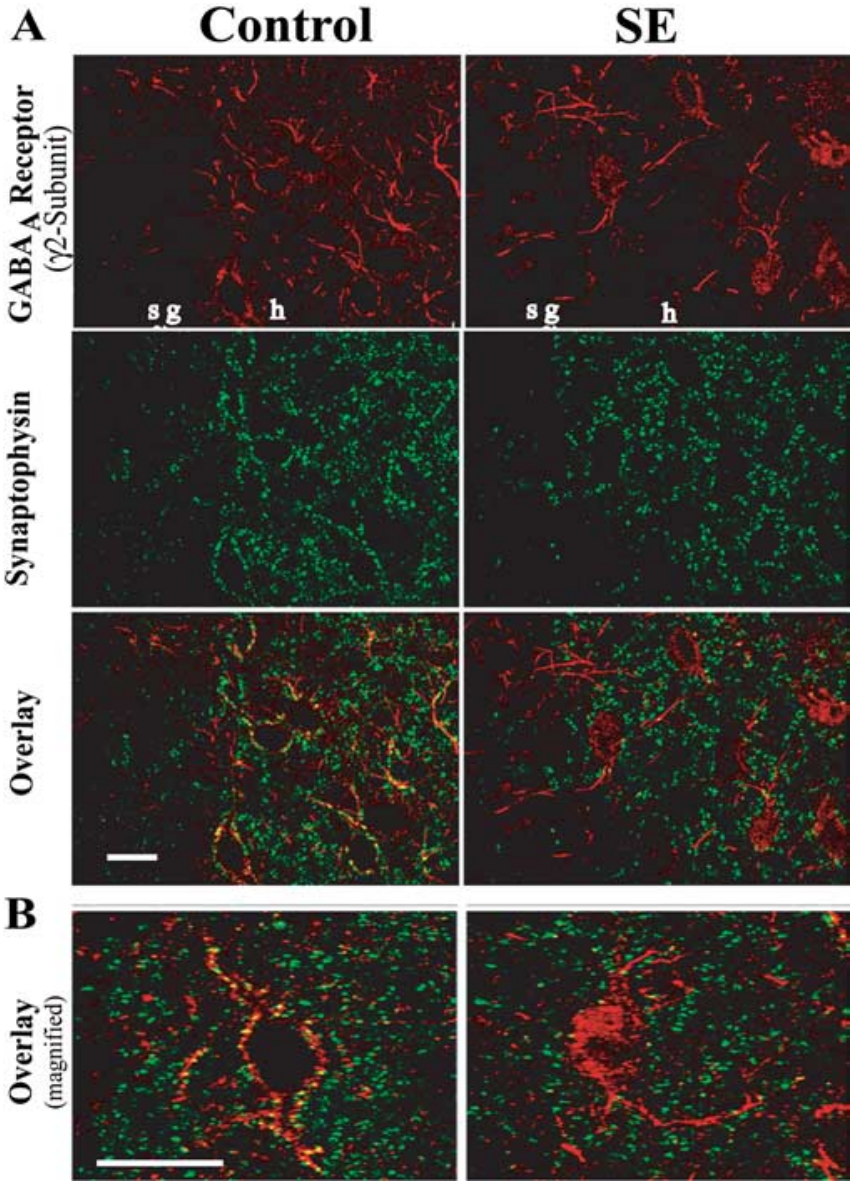

Figure 2. Distribution of $\mathrm{GABA}_{A} \gamma 2$ subunits for SE. A, Hippocampal sections of control (left) and SE (right) stained with an antibody against $\mathrm{GABA}_{\mathrm{A}} \gamma 2$ subunits (red, top) and an antibody against the presynaptic marker synaptophysin (green, middle). Colocalizations in yellow represent overlaps between presynaptic synaptophysin and postsynaptic $G_{A B A_{A}}$ subunit (bottom). $\boldsymbol{B}$, Magnification of the bottom panel in $\boldsymbol{A}$ showing fewer yellow $\mathrm{GABA}_{A}$ subunit puncta colocalizations with synaptophysin and internalization of the red receptor subunits relative to the green synaptophysin outline during SE (right). $s g$, Stratum granulosum; h, hilus. Scale bars, $10 \mu \mathrm{m}$.

dendrites) in granule cell controls to $2 \pm 0.6$ (soma) and $3 \pm 0.6$ (proximal dendrites) with SE $(p<0.001 ; n=3$ animals per group), and the proportion of cells at the edge of the granule cell layer with $>15$ internal $\gamma 2$ subunit-LI increases from $0.19 \pm$ 0.08 in controls to $0.86 \pm 0.04$ with SE $(p<0.001)$ (Fig. 2). Thus, relocation from synapses to the cell interior of at least two subunits, including one associated with benzodiazepine sensitivity, occurs during SE and may contribute to the development of benzodiazepine pharmacoresistance.

\section{A decrease in mIPSC amplitude suggests a loss of} postsynaptic $\mathrm{GABA}_{\mathrm{A}}$ receptors during $\mathrm{SE}$

We used hippocampal slices obtained from animals in lithiumpilocarpine SE for $1 \mathrm{~h}$ to examine whether the internal location of $\beta 2 / \beta 3$ and $\gamma 2$ subunits reflects a decrease in the number of functional postsynaptic $\mathrm{GABA}_{\mathrm{A}}$ receptors. mIPSCs recorded from dentate gyrus granule cells in slices from SE animals decreased peak amplitude to $73 \%$ of controls $(-38.8 \pm 9.2 \mathrm{pA}$ for SE vs $-53.2 \pm 13.4 \mathrm{pA}$ for controls; all data as mean $\pm \mathrm{SD} ; p<0.001$; $n=76)$ and decreased the AUC to $84 \%$ of controls ( $-268 \pm 53$ $\mathrm{pA} \cdot \mathrm{ms}$ for SE vs $-320 \pm 83 \mathrm{pA} \cdot \mathrm{ms}$ for controls). The weighted- $\tau$ decay time (AUC/peak amplitude) increased to $116 \%$ of controls
A
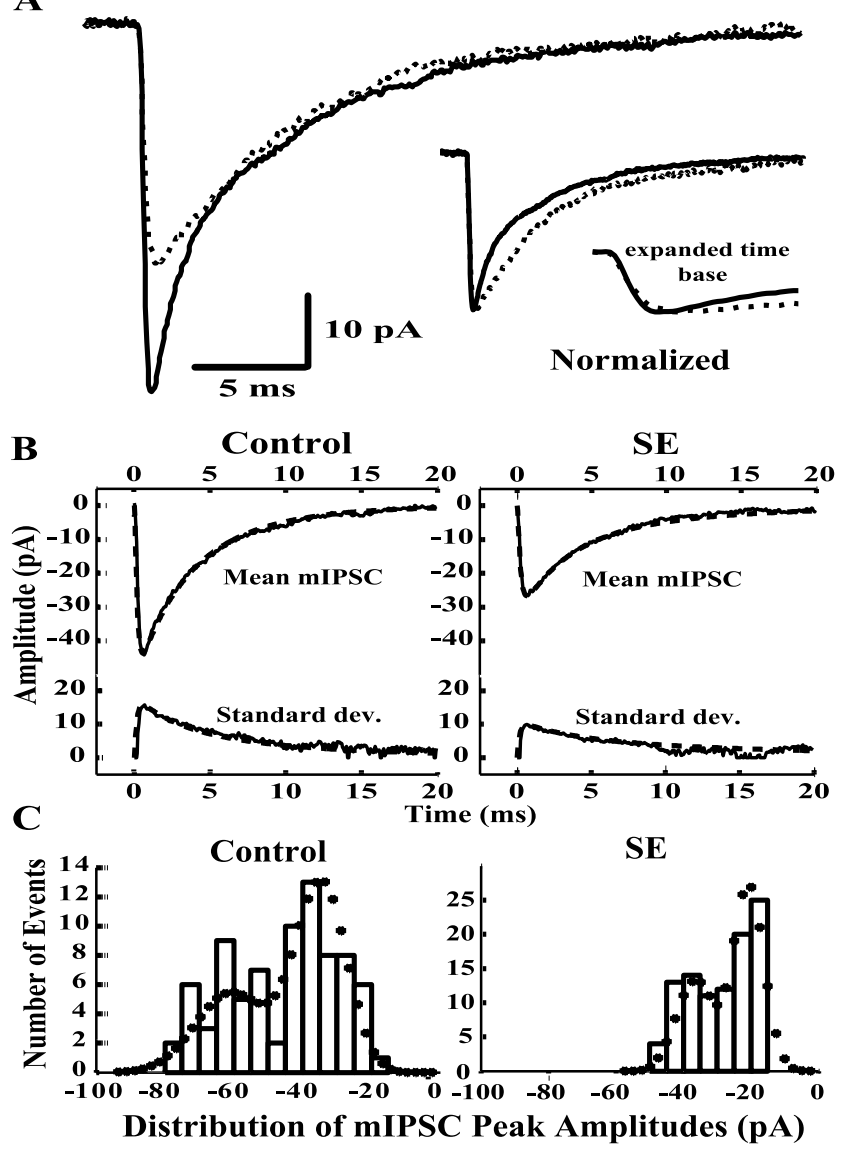

Figure 3. mIPSCs from dentate gyrus granule cells of SE and controls. $A$, mIPSC mean traces from a typical granule cell from a control (solid line) and an SE animal (dotted line) demonstrating smaller amplitude and prolonged decay in the latter. $\boldsymbol{B}$, Optimized computer model fits (dashed line) to mean and SD traces of mIPSCS (solid) from a typical control and an SE cell (see Table 1 for model values). C, Histogram for peak amplitudes of individual mIPSC events recorded from a control (left) and an SE (right) granule cell with the superimposed predicted distribution (filled circles) from model fits of $\boldsymbol{B}$.

$(6.58 \pm 1.27 \mathrm{~ms}$ for SE vs $5.67 \pm 0.87 \mathrm{~ms}$ for controls; $p<0.001)$ (Fig. 3A). Slowing of the $10-90 \%$ rise time $(0.38 \pm 0.09 \mathrm{~ms}$ for SE vs $0.33 \pm 0.05 \mathrm{~ms}$ for controls; $p<0.001)$ and a decrease of mIPSC frequency $(2.16 \pm 1.35 \mathrm{~Hz}$ for SE vs $2.77 \pm 1.39 \mathrm{~Hz}$ for controls; $p<0.001$ ) also occur with SE. mIPSCs recorded in SE slices within $2 \mathrm{~h}$ of decapitation show a greater amplitude decrease (to $62 \%$ of controls; $-31.5 \pm 6.1 \mathrm{pA}$ for SE vs $-51.0 \pm$ $17.0 \mathrm{pA}$ for controls; $p<0.001 ; n=19$ ) and weighted- $\tau$ increase (to $122 \%$ of controls; $7.35 \pm 1.56 \mathrm{~ms}$ for SE vs $6.03 \pm 1.02 \mathrm{~ms}$ for controls; $p<0.001$ ), suggesting recovery during the slice incubation. No significant difference of peak amplitude, AUC, or decay time is observed between lithium control slices and lithium control slices incubated in $40 \mathrm{mg} / \mathrm{L}$ pilocarpine and $1 \mu \mathrm{M}$ tetrodotoxin $(n=24)$, suggesting that the mIPSC differences that we observed with the lithium-pilocarpine model of SE are attributable to SE and not a lithium and/or pilocarpine pharmacological effect.

To explore benzodiazepine responsiveness after SE, we recorded mIPSCs in hippocampal slices from control and SE animals while washing in high concentrations of diazepam $(10 \mathrm{mg} /$ L). After diazepam, a prolongation of MIPSC weighted- $\tau$ decay time (to $120 \pm 19 \%$ of pretreatment for SE, $p<0.001$, paired $t$ test, $n=13$ vs to $117 \pm 10 \%$ of pretreatment for controls, $p<$ 0.001 , paired $t$ test, $n=10$ ) with no increase in IPSC peak 


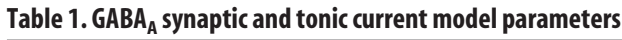

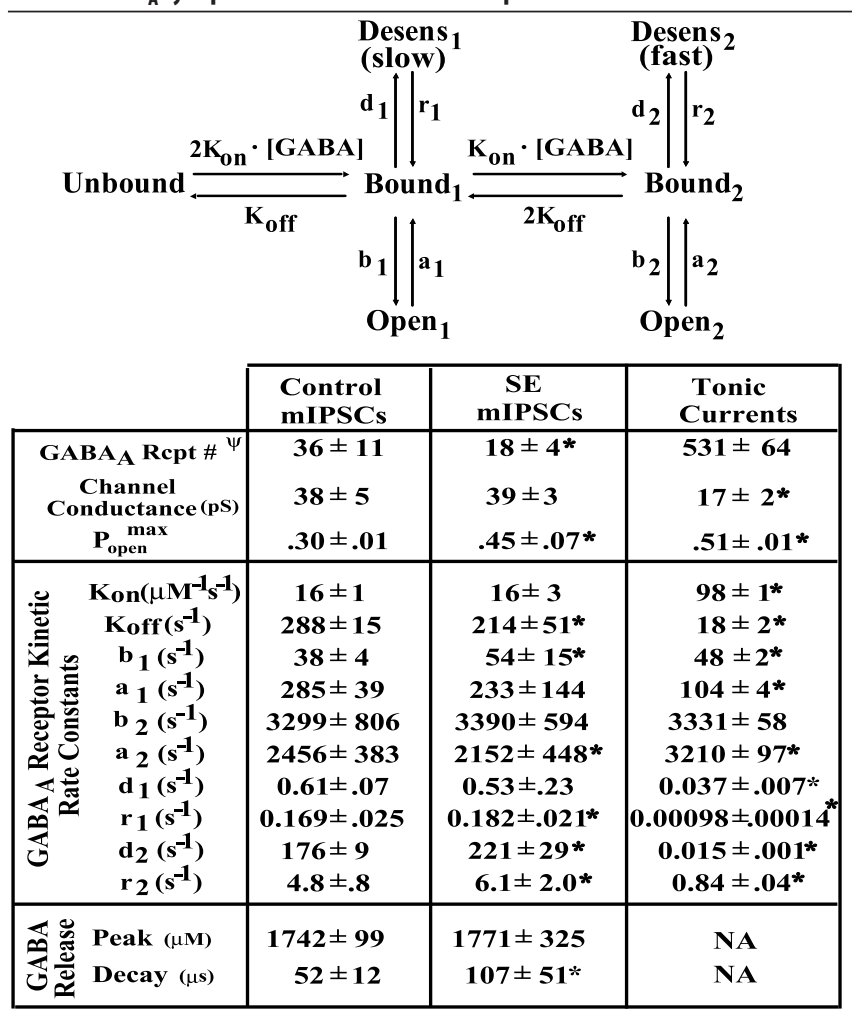

$\psi$ - \# per synapse for control and SE mIPSCs; \# per cell for tonic currents * $-p<.001$ for SE mIPSCs (or tonic currents) compared to control mIPSCs

Top, Schematic showing kinetic rate constants for the seven-state model of the $\mathrm{GABA}_{\mathrm{A}}$ receptor. Bottom, Tabulated model values obtained from optimized fits of mean and SD of mIPSC traces for control ( $n=11$ cells) and SE ( $n=14$ cells) animals (columns 2 and 3). Asterisks in column 3 represent the significant differences of mIPSC SE synaptic parameters compared with mIPSC control values. Column 4 shows optimized model values obtained for fits of $\mathrm{GABA}_{\mathrm{A}}$ tonic current mean and SD measurements for control ( $n=14$ cells) and SE ( $n=12$ cells) animals. Asterisks in column 4 represent significant differences of tonic current receptor parameters compared with synaptic (mIPSC) receptor values. See graphic representation of numerical values (Fig. 4).

amplitude contributes to an increase in mIPSC AUC in dentate granule cells. Despite no significant difference noted with the diazepam effect between cells from SE and control slices, the AUC after diazepam exposure in SE slices still remains $14 \pm 21 \%$ less than the AUC from control cells before diazepam treatment and $20 \pm 20 \%$ less than the AUC from control cells after diazepam treatment $(p<0.01)$. This is because of the smaller initial AUC of mIPSCs after SE compared with controls and suggests an inability of the benzodiazepine to fully restore losses of synaptic inhibition resulting from SE.

To analyze the results, synaptic modeling of $\mathrm{GABA}_{\mathrm{A}}$ receptors (see Materials and Methods, Computer modeling) provides optimized fits to the mean and SD of mIPSCs from control and SE animals and effectively matches the features and peak amplitude distributions of mIPSCs (Fig. $3 B, C$ ). The basic assumptions of the synaptic model are as follows: (1) individual $\mathrm{GABA}_{\mathrm{A}}$ receptors open and close randomly with an open probability determined by the cleft [GABA]; (2) a seven-state kinetic model (including closed, ligand-binding, open, and desensitized states) (Table 1, top) can characterize the relationship between [GABA] and receptor channel open probability (see Materials and Methods, Computer modeling); (3) vesicle release of the transmitter can be modeled as a pulse with exponential decay; and (4) mIPSCs represent the sum of the individual postsynaptic receptor current responses. The results of the model suggest a reduction in postsynaptic receptor number from $36 \pm 11$ per synapse in controls ( $n=11$; consistent with anatomical studies) (Nusser et al., 1998a) to $18 \pm 4$ per synapse in slices obtained after $1 \mathrm{~h}$ of SE $(n=14 ; p<0.001)$ (Table 1$)$.

We suspect that the lower mIPSC frequency that we observed in SE slices is essentially a consequence of the amplitude reduction of mIPSCs during SE (Fig. 3C), which significantly degrades the detection of mIPSC events from baseline noise (supplemental Fig. 1, available at www.jneurosci.org as supplemental material). A contribution from loss of synapses and/or presynaptic effects reducing vesicle release cannot be excluded.

\section{SE causes alterations in synaptic $\mathrm{GABA}_{\mathrm{A}}$ receptor kinetics}

The prolongation of mIPSC decay time observed with SE indicates intrinsic changes with the kinetics of $\mathrm{GABA}_{\mathrm{A}}$ receptor properties and/or with the kinetics of GABA exposure in the synaptic cleft. To distinguish these factors, we tabulated the results across cells (Table 1) for the optimized model fits of the mIPSC mean and SD traces obtained from control and SE slices (Fig. 3B). Model-predicted changes in $\mathrm{GABA}_{\mathrm{A}}$ receptor kinetics include a decrease in the unbinding rate of GABA from the receptor (as reflected by a lowering of $K_{\text {off }}$ from $288 \pm 15 \mathrm{~s}^{-1}$ in controls to $214 \pm 51 \mathrm{~s}^{-1}$ with SE; $p<0.001$ ) (Table 1 ). The predicted, very brief, presence of GABA in the synaptic cleft [transmitter decay of $52 \pm 12 \mu$ s for controls; similar to estimates (Destexhe and Sejnowski, 1995; Clements, 1996) including ultrafast GABA exposure (Pytel et al., 2003)] increases during SE (107 $\pm 51 \mu$ s for SE; $p<0.001$ ) (Fig. 4, top trace) and is associated with an increase of the IIPSC peak $\mathrm{GABA}_{\mathrm{A}}$ receptor open probability $\left(P_{\text {open }}\right.$ max from $0.30 \pm 0.01$ to $0.45 \pm 0.07$ during SE; $p<0.001)$. According to our model, the increase in GABA in the synaptic cleft during SE contributes to $\mathrm{GABA}_{\mathrm{A}}$ receptors rapidly entering into the longlasting desensitized states described in excised patches (Jones and Westbrook, 1995; Overstreet et al., 2000) (Fig. 4, bottom trace). In addition, a slight left shift of the model-predicted doseresponse curve for postsynaptic $\mathrm{GABA}_{\mathrm{A}}$ receptors (Fig. 5C) occurs with SE (also noted with dissociated granule cells) (Kapur and Macdonald, 1997). During SE, we found no significant change of $\mathrm{GABA}_{\mathrm{A}}$ receptor channel conductance compared with controls (estimated at $\sim 38 \mathrm{pS}$ at $34^{\circ} \mathrm{C}$ ). This estimate is larger than measurements of $30 \mathrm{pS}$ with single-channel recordings at room temperature (Bormann, 1988; Lorez et al., 2000), but some variation is not unexpected because of effects of temperature and synaptic clustering on channel properties (Petrini et al., 2003; Everitt et al., 2004).

\section{Increases in tonic $\mathrm{GABA}_{\mathrm{A}}$ currents suggest increases in} extracellular GABA during SE

Unlike the mean amplitude of synaptic mIPSCs, the mean amplitude of tonic currents increased by $240 \%$ in slices from SE rats $(-73.3 \pm 68.2 \mathrm{pA}$ in SE vs $-30.4 \pm 20.4 \mathrm{pA}$ in controls; $p<$ $0.001 ; n=26$ ) (Fig. $5 A$ ). We also note an increase of baseline holding current SD before application of the $\mathrm{GABA}_{\mathrm{A}}$ receptor antagonist SR95531 $(7.8 \pm 3.4 \mathrm{pA}$ for SE and $4.9 \pm 1.8 \mathrm{pA}$ for controls; $p<0.001)$. In vitro measurement of a difference with SE depended on the presence of a GABA uptake inhibitor $(10 \mu \mathrm{M}$ NO711) in the perfusate, presumably because blocking GABA uptake helps preserve the extracellular changes generated by SE in vivo for detection in vitro. Recordings done within $2 \mathrm{~h}$ of killing show an even larger difference for tonic current amplitude $(-130.0 \pm 73.6 \mathrm{pA}$ in SE vs $-44.8 \pm 19.2 \mathrm{pA}$ in controls; $p<$ $0.05 ; n=9)$ and baseline SD (11.05 $\pm 2.31 \mathrm{pA}$ for SE and $6.10 \pm$ $1.53 \mathrm{pA}$ for controls; $p<0.001$ ), whereas cells patched beyond $2 \mathrm{~h}$ after killing show no significant difference in tonic current amplitude $(-32.7 \pm 17.9$ pA for SE vs $-24.6 \pm 18.7 \mathrm{pA}$ in controls; 


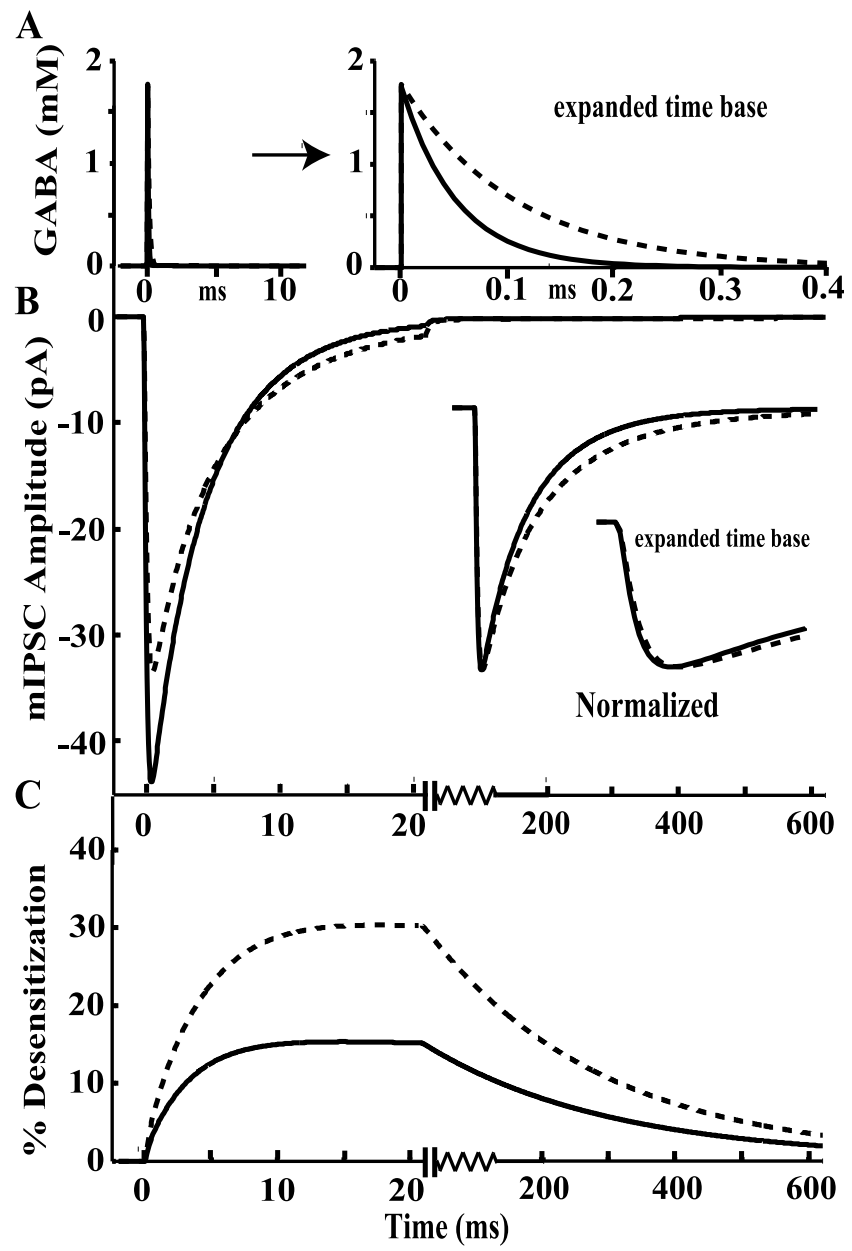

Figure 4. Graphic representation of mIPSC model numerical values (Table 1). The model predictions for control (solid line) and SE (dashed line) amplitudes and time courses are shown for GABA release into the synaptic cleft $(\boldsymbol{A})$, mean $\mathrm{mIPSCS}(\boldsymbol{B})$, and percentage of postsynaptic $G A B A_{A}$ receptors in desensitized states $(\boldsymbol{C})$. Note the predicted prolongation of GABA exposure for $\mathrm{SE}$ in $\boldsymbol{A}$ and the significant persistence of receptors in desensitized states, with greater desensitization for SE in $\boldsymbol{C}$.

$p>0.05 ; n=17)$, suggesting normalization during slice incubation (supplemental Fig. $2 B$, available at www.jneurosci.org as supplemental material).

Previous studies suggest that extrasynaptic $\delta$ subunitcontaining $\mathrm{GABA}_{\mathrm{A}}$ receptors underlie tonic currents in cerebellar and dentate gyrus granule cells (Nusser et al., 1998b; Stell et al., 2003) and that GABA release increases during SE (Walton et al., 1990; Wasterlain et al., 1993). To assess the role of extracellular [GABA] on the tonic current difference with SE, a modelgenerated dose-response curve was optimized to fit the mean and variance of tonic currents from both control and SE cells (Fig. $5 B$ ). Optimization of the variables of Equation 3 for the individual tonic receptor current and numbers per cell (see Materials and Methods, Computer modeling) determine the solid curve. $\mathrm{GABA}_{\mathrm{A}}$ receptor kinetic parameters (Table 1, column 4) subsequently were optimized to determine tonic current means and SDs for $1 \mu \mathrm{M}$ increments of extracellular [GABA], using tonic currents measured from controls with known perfusate [GABA] to constrain the optimization. Because both control and SE cells align the dose-response curve, the difference between the two populations predominantly can be accounted for by micromolar increases in extracellular [GABA] during SE. A slight increase in
A

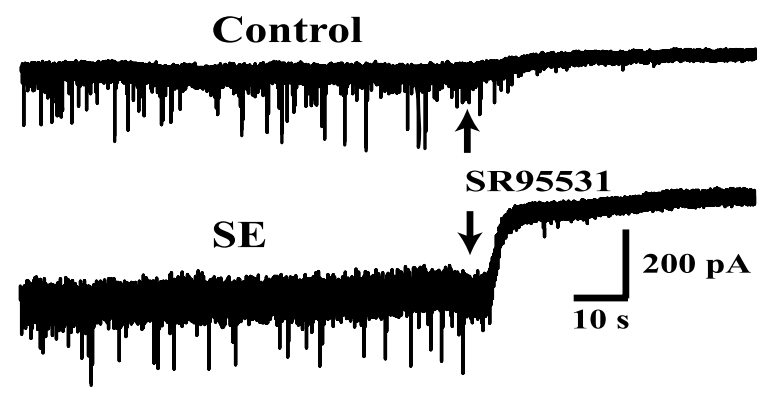

B
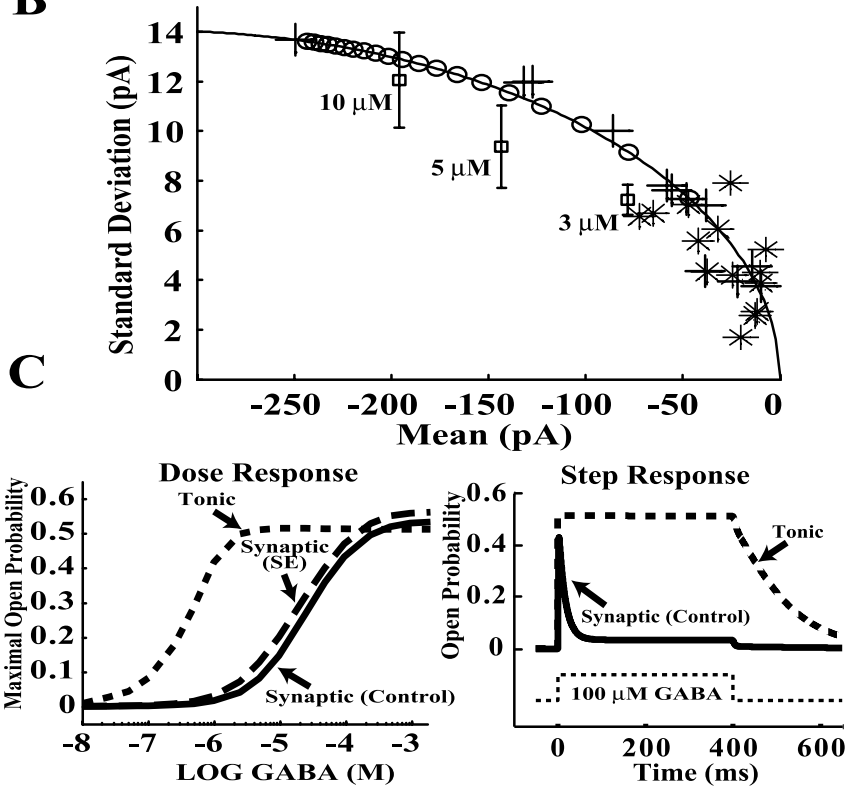

Figure 5. GABA $A_{A}$ tonic currents of granule cells after $S E$. $A$, Recordings from typical cells from control and SE animals. Note the increase mean (and baseline SD) of the tonic current for SE cells compared with controls, as revealed by the greater baseline shift with the addition of the $G A B A_{A}$ receptor antagonist SR95531. Tonic currents for both control and SE cells were accentuated by the addition of the GABA uptake inhibitor N0711 $(10 \mu \mathrm{M})$ and GABA $(1 \mu \mathrm{M}) \cdot \boldsymbol{B}$, Optimized model fit for tonic current means and SDs from control (asterisk; $n=14$ cells) and SE (cross; $n=12$ cells) animals. The solid line curve was the optimization after adjusting $N$ and $i$ of Equation 3 to fit tonic current mean and SD results for control and SE cells. The circles represent modelpredicted dose responses of tonic current mean and SD values (each circle correlates to a $1 \mu \mathrm{m}$ increase in extracellular [GABA] to a total of $20 \mu \mathrm{m}$ ). To calibrate the dose-response predictions of the model, measured tonic current mean and SDs obtained from control experiments with perfusates of known [GABA] are superimposed (3, 5, and $10 \mu \mathrm{m}$ with $10 \mu \mathrm{M}$ N0711; boxes with error bars as $\pm S E M)$. C, Model-predicted $G_{A B A_{A}}$ receptor peak open doseresponse curves (left) and responses for step exposure to GABA (right) using receptor parameter values from optimized fits to mIPSCs of control cells, to mIPSCs of SE cells, and to tonic currents (see Table 1).

the number of extrasynaptic receptors and/or receptor current during SE cannot be excluded, but additional support for the interpretation that an increase in extracellular [GABA] is responsible for the larger tonic currents was provided by experiments that perfused SE and control slices with $100 \mu \mathrm{M}$ saturating [GABA] in the presence of $10 \mu \mathrm{M}$ NO711 to reduce GABA reuptake. Although GABA exposure would be expected to accentuate differences because of changes in receptor number or channel conductance, saturating the receptors with high [GABA] should overwhelm any differences resulting from endogenous increases in extracellular [GABA] with SE. In the presence of 100 $\mu \mathrm{M}[\mathrm{GABA}]$, no significant difference in tonic currents between control and SE slices was observed $(-235 \pm 83 \mathrm{pA}$ for SE vs $-271 \pm 79 \mathrm{pA}$ for controls; $n=28$ ).

The $\mathrm{GABA}_{\mathrm{A}}$ receptor kinetic parameters optimized for the 
tonic currents and phasic (synaptic) mIPSCs (Table 1) were applied to model simulations to generate dose-response curves and step responses (Fig. $5 C$ ). Note the lower $\mathrm{EC}_{50}$ value predicted for tonic current receptors $(0.4 \mu \mathrm{M})$ compared with synaptic receptors $(25 \mu \mathrm{M})$, consistent with the greater binding and lower unbinding rate of GABA for tonic current receptors (as indicated by the increase of $K_{\text {on }}$ and decrease of $K_{\text {off }}$ ) (Table 1) (Stell and Mody, 2002). In addition, fast desensitization with step responses is predicted for synaptic receptors, whereas slow desensitization is noted for tonic receptors (Fig. 5C). The model responses to GABA steps and the $\mathrm{EC}_{50}$ values of our model dose-response curves for synaptic (or tonic) receptors correlate well with results for in vitro expression systems using $\gamma 2$ (or $\delta$ )-containing subunits, respectively (Saxena and Macdonald, 1996; Haas and Macdonald, 1999; Brown et al., 2002).

GABA exposure may contribute to diminished synaptic GABA $_{\mathrm{A}}$ inhibition and loss of paired-pulse inhibition

We have shown in vivo that brief (1-3 min) seizure-like stimulation of the perforant path causes a lasting $(43 \pm 15 \mathrm{~min})$ loss of paired-pulse inhibition (PPI) in the dentate gyrus (Naylor, 2002). To assess how SE could affect PPI, the model for individual synapses was adapted to fit perforant path-evoked IPSCs of dentate granule cells in slices (Fig. 6A). Adjustable parameters were for the number of inhibitory synapses and linear filtering constants, whereas synaptic parameters were defined from previous mIPSC fits and treated as fixed constants for this stage of the modeling (see Materials and Methods, Computer modeling). After this optimization, delivery of paired pulses to the evoked model using either the control or SE parameter values (Table 1) shows a loss of PPI with the latter (Fig. 6B). The model-predicted PPI as assessed by paired-pulse ratios $(\mathrm{P} 2 / \mathrm{P} 1)$ is reduced $35 \%$ with $\mathrm{SE}$. A similar loss of PPI (attributed to effects at postsynaptic $\mathrm{GABA}_{\mathrm{A}}$ receptors) has been observed with evoked IPSCs using an in vitro representation of the perforant path stimulation model of SE (Naylor and Wasterlain, 2005). Although paired-pulse responses can be influenced by many factors that are not accounted for by this model (e.g., presynaptic probability of release), our results suggest that diminished postsynaptic $\mathrm{GABA}_{\mathrm{A}}$ receptor inhibition is an important and early element in the loss of PPI. The primary variable responsible for the model-predicted loss of PPI using the SE parameters is the increase in extracellular [GABA] to $5 \mu \mathrm{M}$, suggesting that increased [GABA] at the synapse may occur rapidly during SE [because loss of PPI is observed within minutes (Naylor, 2002)]. If this is correct, one would predict that exposure of hippocampal slices to elevated [GABA] in the perfusate would mimic the changes in synaptic and in tonic currents observed during SE. Indeed, a $45 \%$ decrease in mIPSC amplitude $(-28.0 \pm 6.7 \mathrm{pA}$ after exposure vs $-51.3 \pm 15.2 \mathrm{pA}$ before; $p<$ $0.001 ; n=13$ ) and a tonic current increase (Fig. $5 B$ ) are noted within 20 min when control slices are exposed to perfusates with $3 \mu \mathrm{M}$ GABA (with the GABA uptake inhibitor NO711), mimicking many effects of SE.

\section{Discussion}

After 1 h of SE, we estimate that dentate granule cells have a $50 \%$ decrease in the number of physiologically active $\mathrm{GABA}_{\mathrm{A}}$ receptors per granule cell synapse and a 69 and $76 \%$ reduction, respectively, of the number of $\beta 2 / \beta 3$ and $\gamma 2$ subunit-like immunoreactivity in the vicinity of the presynaptic marker synaptophysin. Normalization of synaptic physiology with incubation after slice preparation (which arrests seizures) may explain the lower estimate obtained from mIPSC analysis compared with immunocy-

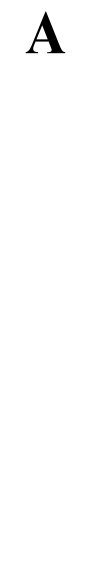

B

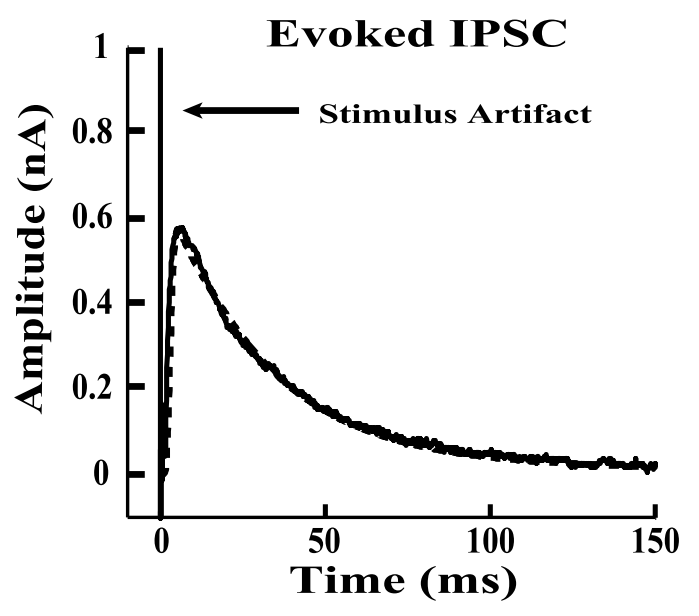

Predicted Paired-Pulse Responses

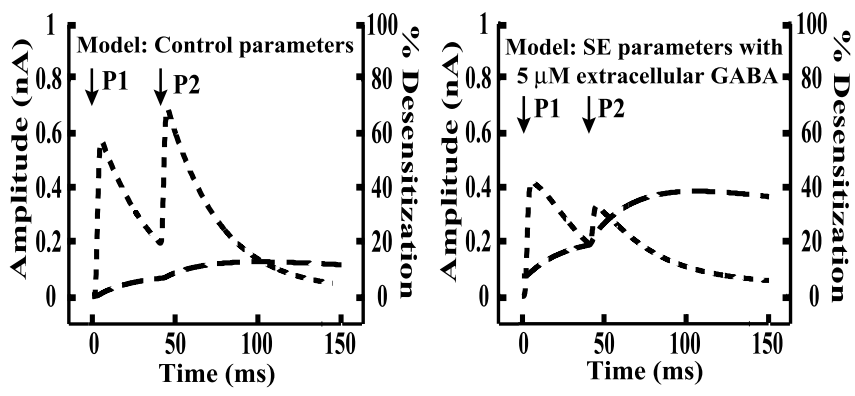

Figure 6. Perforant path-evoked IPSCS and model-predicted paired-pulse responses for dentate granule cells. $\boldsymbol{A}$, Typical evoked IPSC recording (solid line) in a control animal with optimized fit by a model (dashed line) for evoked activation (see Materials and Methods, Computer modeling). $\boldsymbol{B}$, Model-predicted evoked paired-pulse responses (interstimulus interval of $40 \mathrm{~ms}$ ) in granule cells using synaptic parameters from fits of mIPSCs from control (left) and SE (right) cells, also using elevated tonic extracellular [GABA] for SE conditions (estimated from increased tonic currents with SE). Predicted evoked currents (short-dashed line) and percentage of $\mathrm{GABA}_{A}$ receptor desensitization (long-dashed line) show loss of paired-pulse inhibition and greater desensitization under SE conditions (P2/P1 from 1.21 for control to 0.79 for SE parameters). For SE conditions in the model, the slight desensitization of synaptic receptors before the paired pulses is a result of $5 \mu \mathrm{m}$ extracellular GABA.

tochemistry (supplemental Fig. 2A, available at www.jneurosci. org as supplemental material). A commensurate increase in $\beta 2 / \beta 3$ and $\gamma 2$ subunit-LI in the cytoplasm suggests that the subunits relocate to the cell interior during SE, possibly through endocytosis or decreased recycling to the surface. This loss of physiologically active receptors is mimicked by a 20 min exposure of slices to GABA, suggesting that an increase in GABA release with seizure activity may be a contributing factor.

The reduction of $\mathrm{GABA}_{\mathrm{A}}$ synaptic receptors may characterize the key transition in which the potent intrinsic mechanisms that usually stop seizures fail and SE becomes self-sustaining (Mazarati et al., 1998a). Of note, the time course for the loss of benzodiazepine responsiveness, which fails between 10 and $45 \mathrm{~min}$ of SE (Kapur and Macdonald, 1997), parallels the emergence of self-sustaining SE in both the perforant-path stimulation (Mazarati et al., 1998a) and lithium-pilocarpine models (L. Suchomelova and C. Wasterlain, personal communication). Furthermore, a loss of inhibition exceeding 30\%, as assessed by paired-pulse inhibition, is predicted to result in spontaneous seizures (Kapur and Lothman, 1989), and the seizures also cause a loss of paired-pulse inhibition (Kapur and Lothman, 1989; Kapur et al., 1989). Because our model results suggest a 35\% loss of 
paired-pulse inhibition after $1 \mathrm{~h}$ of SE, a threshold may be exceeded for generating spontaneous seizures that, in turn, may sustain the loss of inhibition.

The differential effect of SE on the amplitude of phasic (mIPSC) compared with tonic currents may be explained by differences in $\mathrm{GABA}_{\mathrm{A}}$ receptor subunit compositions that underlie each current type. $\mathrm{GABA}_{\mathrm{A}}$ receptors containing the $\gamma 2$ subunit are associated with sensitivity to benzodiazepines (Saxena and Macdonald, 1996) and markedly desensitize to GABA exposure (Haas and Macdonald, 1999). The $\gamma 2$ subunit in receptors contained at synapses associates with the synaptic clustering molecule gephyrin (Essrich et al., 1998; Nusser et al., 1998b), interacts with the adaptin AP2 complex for clathrin-dependent endocytosis (Connolly et al., 1999; Kittler et al., 2000), and has several consensus sequences for phosphorylation at serine-threonine and tyrosine sites that affect receptor kinetics, desensitization, and/or receptor internalization (Krishek et al., 1994; Martina et al., 1996; Wan et al., 1997; Amico et al., 1998; Connolly et al., 1999; Kittler and Moss, 2003; Wang et al., 2003a,b). Conversely, extrasynaptic receptors that contain the $\delta$ subunit (Nusser et al., 1998b) show little desensitization or benzodiazepine sensitivity (Saxena and Macdonald, 1996; Haas and Macdonald, 1999; Brown et al., 2002).

Our model results suggest that a $5-10 \mu \mathrm{M}$ increase in extracellular [GABA] during SE is sufficient to explain the increase of extrasynaptic tonic currents that we observed, whereas increased [GABA] at synapses can result in desensitization and internalization of postsynaptic $\mathrm{GABA}_{\mathrm{A}}$ receptors. Supporting this, SE increases GABA release (Walton et al., 1990; Wasterlain et al., 1993), consistent with increases in cell-firing elevating $\mathrm{GABA}_{\mathrm{A}}$ tonic currents (Brickley et al., 1996), micromolar levels of extracellular [GABA] can desensitize $\mathrm{GABA}_{\mathrm{A}}$ receptors (Overstreet et al., 2000), and increased agonist exposure contributes to endocytosis of $\mathrm{GABA}_{\mathrm{A}}$ receptors (Barnes, 1996). Furthermore, $5 \mu \mathrm{M}$ GABA in the perfusate causes mIPSC amplitude decreases and tonic current increases (Overstreet and Westbrook, 2001), similar to those that we found for SE. It is difficult to assess how much an increase in extracellular GABA during SE can increase GABA tonic currents in vivo (and counterbalance the loss of synaptic inhibition), because our measurements of tonic currents reflect slice conditions in the presence of GABA uptake inhibitors.

It is unlikely that the decrease in synaptic mIPSC and increase in tonic current amplitudes result from a shift of receptors from synaptic to extrasynaptic locations. Although lateral diffusion of $\mathrm{GABA}_{\mathrm{A}}$ receptors might explain the decreased colocalization of receptor subunits at the synapse, it would not explain the increased immunoreactivity in the cytoplasm for both $\beta 2 / \beta 3$ and $\gamma 2$ subunits. In addition, because the synaptic receptors containing the $\gamma 2$ subunit rapidly desensitize (Haas and Macdonald, 1999; Overstreet et al., 2000), movement of synaptic receptors to extrasynaptic sites should not account for the increased tonic currents, and our model results suggest that the increased tonic currents with SE result from elevated extracellular [GABA] rather than an increase in extrasynaptic receptor number or single channel current. Additional experiments using antibodies to $\delta$ subunits to test these interpretations are in progress.

Signal transduction pathways activated during SE also have important modulatory effects on $\mathrm{GABA}_{\mathrm{A}}$ receptors, affecting both phosphorylation state and internalization. For example, calcineurin activation causes $\gamma 2$ subunit dephosphorylation and a decrease of functional postsynaptic $\mathrm{GABA}_{\mathrm{A}}$ receptors with synaptic depression (Wang et al., 2003a), and calcineurin activity is potentiated during SE (Kurz et al., 2001). We found an increase in
NMDA currents during SE (D.E. Naylor, H. Liu, and C.G. Wasterlain, unpublished observations), which could facilitate calcium potentiation of such a mechanism. Loss of GABAergic inhibition in some models of epilepsy has been attributed to NMDA receptor activation (Kapur and Lothman, 1990). Although our prediction of longer exposure of receptors to cleft GABA during SE can explain the prolongation of mIPSC decay, calcineurin can prolong IPSCs as well (Jones and Westbrook, 1997). Protein kinase $C$ also is activated during seizures (Osonoe et al., 1994), and the $\beta$ subunits of $\mathrm{GABA}_{\mathrm{A}}$ receptors have consensus sequences for phosphorylation by protein kinase $\mathrm{C}$ (Connolly et al., 1999; Kittler and Moss, 2003) and other kinases/ phosphatases that affect delivery of $\mathrm{GABA}_{\mathrm{A}}$ receptors to the cell surface (Wan et al., 1997; Wang et al., 2003a,b). In addition to desensitization and/or phosphorylation, variation in $\mathrm{GABA}_{\mathrm{A}}$ subunit compositions affects mIPSC kinetics and seizure threshold (McIntyre et al., 2002), suggesting that selective subunit internalization could shape mIPSC kinetics as well.

It is likely that multiple mechanisms contribute to the mIPSC amplitude and kinetic changes in hippocampal granule cells during SE. Because the dentate gyrus is an important gatekeeper for the propagation of epileptiform activity, the changes we observe in granule cells should have significant effects on the spread of seizures within and outside the hippocampus (Heinemann et al., 1992). Our results suggest that SE-induced changes at $\mathrm{GABA}_{\mathrm{A}}$ synapses can account for loss of paired-pulse inhibition in the dentate gyrus, providing a basis for early breakdown of its gatekeeper function with SE. We also found that CA1 pyramidal cells and hilar neurons display $\mathrm{GABA}_{\mathrm{A}}$ receptor subunit internalization, suggesting more distributed effects on GABAergic inhibition in the hippocampus during SE.

Relocation of $\mathrm{GABA}_{\mathrm{A}}$ receptors from synapses to the cell interior helps explain receptor losses observed physiologically, and the resulting decrease in the availability of receptors for ligand binding may be responsible for the time-dependent, progressive decrease in efficacy of benzodiazepines during SE in vivo (Walton and Treiman, 1988; Mazarati et al., 1998b) and for the reduction in benzodiazepine potency in vitro in dissociated neurons isolated from animals in SE (Kapur and Macdonald, 1997). It also could account for the observation that, in humans, benzodiazepines are effective in early SE but not in late SE (Treiman et al., 1998). After SE, we found that mIPSCs of granule cells do respond to high-diazepam concentrations, but the response is insufficient to restore synaptic inhibition to control levels (compatible with a reduced number of synaptic $\mathrm{GABA}_{\mathrm{A}}$ receptors).

Several clinical implications have emerged. First, the functional loss of $\mathrm{GABA}_{\mathrm{A}}$ receptors resulting from subunit trafficking may explain the time-dependent development of pharmacoresistance to GABAergic agents in SE and represents a new mechanism of pharmacoresistance that might have implications beyond SE (de Krom et al., 1995; Ali and Olsen, 2001; Fitzek et al., 2001; Kumar et al., 2003). Our findings emphasize the importance of recognizing a crucial time window for delivery of GABAenhancing medications during SE, stress the role of additional pharmacotherapies for effective treatment (including those directed against glutamatergic excitation), and may explain timedependent relationships for different anticonvulsants (Walton and Treiman, 1991; Jones et al., 2002). A mechanism is proposed in the acute situation of SE whereby "seizures beget seizures." Persistent cell firing and GABA release during seizures may lead to accumulation of GABA, desensitization and internalization of postsynaptic $\mathrm{GABA}_{\mathrm{A}}$ receptors with ultimate failure of inhibition, and the emergence of self-sustaining seizures and continu- 
ation of the vicious cycle of cell firing. Because NMDA activation during SE may contribute to downregulation of GABAergic inhibition (Wang et al., 2003a), NMDA antagonism may not only oppose excess glutamatergic excitation but enhance inhibition as well. Novel approaches for treatment of SE might include manipulation of the $\mathrm{GABA}_{\mathrm{A}}$ receptor phosphorylation or desensitization state, prevention of receptor endocytosis with osmotic agents such as mannitol (Heuser and Anderson, 1989), and management of the intracellular signal pathways for $\mathrm{GABA}_{\mathrm{A}}$ receptor trafficking. Additional potentiation of tonic currents by modulators such as neurosteroids (Stell et al., 2003) may also be possible.

\section{References}

Ali NJ, Olsen RW (2001) Chronic benzodiazepine treatment of cells expressing recombinant $\mathrm{GABA}_{\mathrm{A}}$ receptors uncouples allosteric binding: studies on possible mechanisms. J Neurochem 79:1100-1108.

Amico C, Cupello A, Fossati C, Robello M (1998) Involvement of phosphatase activities in the run-down of $\mathrm{GABA}_{\mathrm{A}}$ receptor function in rat cerebellar granule cells in culture. Neuroscience 84:529-535.

Barnes Jr EM (1996) Use-dependent regulation of $\mathrm{GABA}_{\mathrm{A}}$ receptors. Int Rev Neurobiol 39:53-76.

Bormann J (1988) Electrophysiology of $\mathrm{GABA}_{\mathrm{A}}$ and $\mathrm{GABA}_{\mathrm{B}}$ receptor subtypes. Trends Neurosci 11:112-116.

Brickley SG, Cull-Candy SG, Farrant M (1996) Development of a tonic form of synaptic inhibition in rat cerebellar granule cells resulting from persistent activation of $\mathrm{GABA}_{\mathrm{A}}$ receptors. J Physiol (Lond) 497:753-759.

Brickley SG, Cull-Candy SG, Farrant M (1999) Single-channel properties of synaptic and extrasynaptic $\mathrm{GABA}_{\mathrm{A}}$ receptors suggest differential targeting of receptor subtypes. J Neurosci 19:2960-2973.

Brown N, Kerby J, Bonnert TP, Whiting PJ, Wafford KA (2002) Pharmacological characterization of a novel cell line expressing human $\alpha 4 \beta 3 \delta$ $\mathrm{GABA}_{\mathrm{A}}$ receptors. Br J Pharmacol 136:965-974.

Clements JD (1996) Transmitter time course in the synaptic cleft: its role in central synaptic function. Trends Neurosci 19:163-171.

Connolly CN, Kittler JT, Thomas P, Uren JM, Brandon NJ, Smart TG, Moss SJ (1999) Cell surface stability of $\gamma$-aminobutyric acid type A receptors. Dependence on protein kinase C activity and subunit composition. J Biol Chem 274:36565-36572.

de Krom MC, Verduin N, Visser E, Kleijer M, Scholtes F, De Groen JH (1995) Status epilepticus during vigabatrin treatment: a report of three cases. Seizure 4:159-162.

DeLorenzo RJ, Hauser WA, Towne AR, Boggs JG, Pellock JM, Penberthy L, Garnett L, Fortner CA, Ko D (1996) A prospective, population-based epidemiologic study of status epilepticus in Richmond, Virginia. Neurology 46:1029-1035.

Destexhe A, Sejnowski TJ (1995) G protein activation kinetics and spillover of gamma-aminobutyric acid may account for differences between inhibitory responses in the hippocampus and thalamus. Proc Natl Acad Sci USA 92:9515-9519.

Essrich C, Lorez M, Benson JA, Fritschy JM, Luscher B (1998) Postsynaptic clustering of major $\mathrm{GABA}_{\mathrm{A}}$ receptor subtypes requires the $\gamma 2$ subunit and gephyrin. Nat Neurosci 1:563-571.

Everitt AB, Luu T, Cromer B, Tierney ML, Birnir B, Olsen RW, Gage PW (2004) Conductance of recombinant $\mathrm{GABA}_{\mathrm{A}}$ channels is increased in cells co-expressing $\mathrm{GABA}_{\mathrm{A}}$ receptor-associated protein. J Biol Chem 279:21701-21706.

Fitzek S, Hegemann S, Sauner D, Bonsch D, Fitzek C (2001) Drug-induced nonconvulsive status epilepticus with low dose of tiagabine. Epileptic Disord 3:147-150.

Gunther U, Benson J, Benke D, Fritschy JM, Reyes G, Knoflach F, Crestani F, Aguzzi A, Arigoni M, Lang Y, Bluethmann H, Mohler H, Luscher B (1995) Benzodiazepine-insensitive mice generated by targeted disruption of the $\gamma 2$ subunit gene of $\gamma$-aminobutyric acid type A receptors. Proc Natl Acad Sci USA 92:7749-7753.

Haas KF, Macdonald RL (1999) GABA $_{A}$ receptor subunit $\gamma 2$ and $\delta$ subtypes confer unique kinetic properties on recombinant $\mathrm{GABA}_{\mathrm{A}}$ receptor currents in mouse fibroblasts. J Physiol (Lond) 514:27-45.

Heinemann U, Beck H, Dreier JP, Ficker E, Stabel J, Zhang CL (1992) The dentate gyrus as a regulated gate for the propagation of epileptiform activity. Epilepsy Res Suppl 7:273-280.

Heuser JE, Anderson RG (1989) Hypertonic media inhibit receptor- mediated endocytosis by blocking clathrin-coated pit formation. J Cell Biol 108:389-400.

Jones DM, Esmaeil N, Maren S, Macdonald RL (2002) Characterization of pharmacoresistance to benzodiazepines in the rat Li-pilocarpine model of status epilepticus. Epilepsy Res 50:301-312.

Jones MV, Westbrook GL (1995) Desensitized states prolong $\mathrm{GABA}_{\mathrm{A}}$ channel responses to brief agonist pulses. Neuron 15:181-191.

Jones MV, Westbrook GL (1997) Shaping of IPSCs by endogenous calcineurin activity. J Neurosci 17:7626-7633.

Kapur J, Lothman EW (1989) Loss of inhibition precedes delayed spontaneous seizures in the hippocampus after tetanic electrical stimulation. J Neurophysiol 61:427-434.

Kapur J, Lothman EW (1990) NMDA receptor activation mediates the loss of GABAergic inhibition induced by recurrent seizures. Epilepsy Res 5:103-111.

Kapur J, Macdonald RL (1997) Rapid seizure-induced reduction of benzodiazepine and $\mathrm{Zn}^{2+}$ sensitivity of hippocampal dentate granule cell $\mathrm{GABA}_{\mathrm{A}}$ receptors. J Neurosci 17:7532-7540.

Kapur J, Stringer JL, Lothman EW (1989) Evidence that repetitive seizures in the hippocampus cause a lasting reduction of GABAergic inhibition. J Neurophysiol 61:417-426.

Kittler JT, Moss SJ (2003) Modulation of GABA $\mathrm{A}_{\mathrm{A}}$ receptor activity by phosphorylation and receptor trafficking: implications for the efficacy of synaptic inhibition. Curr Opin Neurobiol 13:341-347.

Kittler JT, Delmas P, Jovanovic JN, Brown DA, Smart TG, Moss SJ (2000) Constitutive endocytosis of $\mathrm{GABA}_{\mathrm{A}}$ receptors by an association with the adaptin AP2 complex modulates inhibitory synaptic currents in hippocampal neurons. J Neurosci 20:7972-7977.

Krishek BJ, Xie X, Blackstone C, Huganir RL, Moss SJ, Smart TG (1994) Regulation of $\mathrm{GABA}_{\mathrm{A}}$ receptor function by protein kinase $\mathrm{C}$ phosphorylation. Neuron 12:1081-1095.

Kumar S, Kralic JE, O’Buckley TK, Grobin AC, Morrow AL (2003) Chronic ethanol consumption enhances internalization of $\alpha 1$ subunit-containing $\mathrm{GABA}_{\mathrm{A}}$ receptors in cerebral cortex. J Neurochem 86:700-708.

Kurz JE, Sheets D, Parsons JT, Rana A, Delorenzo RJ, Churn SB (2001) A significant increase in both basal and maximal calcineurin activity in the rat pilocarpine model of status epilepticus. J Neurochem 78:304-315.

Lagarias JC, Reeds JA, Wright MH, Wright PE (1998) Convergence properties of the Nelder-Mead simplex method in low dimensions. SIAM J Optimiz 9:112-147.

Lorez M, Benke D, Luscher B, Mohler H, Benson JA (2000) Single-channel properties of neuronal $\mathrm{GABA}_{\mathrm{A}}$ receptors from mice lacking the $\gamma 2$ subunit. J Physiol (Lond) 527:11-31.

Martina M, Mozrzymas JW, Boddeke HW, Cherubini E (1996) The calcineurin inhibitor cyclosporin A-cyclophilin A complex reduces desensitization of $\mathrm{GABA}_{\mathrm{A}}$-mediated responses in acutely dissociated rat hippocampal neurons. Neurosci Lett 215:95-98.

Mazarati AM, Wasterlain CG, Sankar R, Shin D (1998a) Self-sustaining status epilepticus after brief electrical stimulation of the perforant path. Brain Res 801:251-253.

Mazarati AM, Baldwin RA, Sankar R, Wasterlain CG (1998b) Timedependent decrease in the effectiveness of antiepileptic drugs during the course of self-sustaining status epilepticus. Brain Res 814:179-185.

McIntyre DC, Hutcheon B, Schwabe K, Poulter MO (2002) Divergent $\mathrm{GABA}_{\mathrm{A}}$ receptor-mediated synaptic transmission in genetically seizureprone and seizure-resistant rats. J Neurosci 22:9922-9931.

Naylor D (2002) Changes in nonlinear signal processing in rat hippocampus associated with loss of paired-pulse inhibition or epileptogenesis. Epilepsia 43 [Suppl 5]:188-193.

Naylor DE, Wasterlain CG (2005) GABA synapses and the rapid loss of inhibition to dentate gyrus cells after brief perforant path stimulation. Epilepsia 46 [Suppl 5]:142-147.

Nusser Z, Hájos N, Somogyi P, Mody I (1998a) Increased number of synaptic $\mathrm{GABA}_{\mathrm{A}}$ receptors underlies potentiation at hippocampal inhibitory synapses. Nature 395:172-177.

Nusser Z, Sieghart W, Somogyi P (1998b) Segregation of different GABA $A_{A}$ receptors to synaptic and extrasynaptic membranes of cerebellar granule cells. J Neurosci 18:1693-1703.

Osonoe K, Ogata S, Iwata Y, Mori N (1994) Kindled amygdaloid seizures in rats cause immediate and transient increase in protein kinase $\mathrm{C}$ activity followed by transient suppression of the activity. Epilepsia 35:850-854. 
Overstreet LS, Westbrook GL (2001) Paradoxical reduction of synaptic inhibition by vigabatrin. J Neurophysiol 86:596-603.

Overstreet LS, Jones MV, Westbrook GL (2000) Slow desensitization regulates the availability of synaptic $\mathrm{GABA}_{\mathrm{A}}$ receptors. J Neurosci 20:7914-7921.

Petrini EM, Zacchi P, Barberis A, Mozrzymas JW, Cherubini E (2003) Declusterization of $\mathrm{GABA}_{\mathrm{A}}$ receptors affects the kinetic properties of GABAergic currents in cultured hippocampal neurons. J Biol Chem 278:16271-16279.

Pytel M, Mercik K, Mozrzymas JW (2003) Resolving the ionotropic receptor kinetics and modulation in the time scale of synaptic transmission. Cell Mol Biol Lett 8:231-241.

Racine RJ (1972) Modification of seizure activity by electrical stimulation. II. Motor seizure. Electroencephalogr Clin Neurophysiol 32:281-294.

Saxena NC, Macdonald RL (1996) Properties of putative cerebellar $\gamma$-aminobutyric acid $_{\mathrm{A}}$ receptor isoforms. Mol Pharmacol 49:567-579.

Stell BM, Mody I (2002) Receptors with different affinities mediate phasic and tonic $\mathrm{GABA}_{\mathrm{A}}$ conductances in hippocampal neurons. J Neurosci 22:RC223(1-5).

Stell BM, Brickley SG, Tang CY, Farrant M, Mody I, Stell B (2003) Neuroactive steroids reduce neuronal excitability by selectively enhancing tonic inhibition mediated by $\delta$ subunit-containing $\mathrm{GABA}_{\mathrm{A}}$ receptors. Proc Natl Acad Sci USA 100:14439-14444.

Treiman DM (1995) Electroclinical features of status epilepticus. J Clin Neurophysiol 12:343-362.

Treiman DM, Meyers PD, Walton NY, Collins JF, Colling C, Rowan AJ, Handforth A, Faught E, Calabrese VP, Uthman BM, Ramsay RE, Mamdani MB (1998) A comparison of four treatments for generalized con- vulsive status epilepticus. Veterans Affairs status epilepticus cooperative study group. N Engl J Med 339:792-798.

Walton NY, Treiman DM (1988) Response of status epilepticus induced by lithium and pilocarpine to treatment with diazepam. Exp Neurol 101:267-275.

Walton NY, Treiman DM (1991) Motor and electroencephalographic response of refractory experimental status epilepticus in rats to treatment with MK-801, diazepam, or MK-801 plus diazepam. Brain Res 553:97-104.

Walton NY, Gunawan S, Treiman DM (1990) Brain amino acid concentration changes during status epilepticus induced by lithium and pilocarpine. Exp Neurol 108:61-70.

Wan Q, Xiong ZG, Man HY, Ackerley CA, Braunton J, Lu WY, Becker LE, MacDonald JF, Wang YT (1997) Recruitment of functional GABA A $_{\mathrm{A}}$ receptors to postsynaptic domains by insulin. Nature 388:686-690.

Wang J, Liu S, Haditsch U, Tu W, Cochrane K, Ahmadian G, Tran L, Paw J, Wang Y, Mansuy I, Salter MM, YouMing L (2003a) Interaction of calcineurin and type-A GABA receptor $\gamma 2$ subunits produces long-term depression at CA1 inhibitory synapses. J Neurosci 23:826-836.

Wang Q, Liu L, Pei L, Ju W, Ahmadian G, Lu J, Wang Y, Liu F, Wang YT (2003b) Control of synaptic strength, a novel function of Akt. Neuron 38:915-928.

Wasterlain CG, Baxter CF, Baldwin RA (1993) GABA metabolism in the substantia nigra, cortex, and hippocampus during status epilepticus. Neurochem Res 18:527-532.

Zar JH (1999) Biostatistical analysis, Ed 4. Upper Saddle River, NJ: Prentice Hall. 